\title{
So, Catalogers Are Scarce
}

\author{
BY JOHN ZIMMERMAN
}

The Administrator of the small college library does not need to be told about the scarcity of catalogers, especially if he has tried to find one to complete his staff. For several years the situation in the library at the Frostburg State Teachers College in western Maryland had remained the same: only one half-time cataloger was available in spite of repeated and diligent efforts to locate a qualified full-time person. The annual net gain of additions to the collection hovered around a thousand volumes. The student body had doubled in five years (1300 in September 1962), and the curriculum was expanding rapidly. More and more demands were being made on the library.

Meanwhile, a backlog of uncataloged books was piling up because the halftime cataloger could not handle the swelling flow of new purchases and at the same time keep up with the problem of recataloging necessary to correcting past inconsistencies before new materials could be properly added. The annual report of the librarian in 1961 told the president of the college that a crisis existed in the library: unless special help was obtained to catalog the new books being purchased great inconveniences were certain to arise, and faculty members would not be able to use material they wanted and needed for classes.

The president had demonstrated his interest in the library the previous year by inviting a survey team to study the library and to make recommendations. The recommendations were being followed insofar as possible and, in a way, were responsible for part of the problem: additional funds over and above the regular budget had been recommended by the survey committee to improve and to increase the holdings of the library.
Mr. Zimmerman has, since 1957, been Librarian of the State Teachers College at Frostburg, Maryland. He is a graduate of Emory University's Division of Librarianship.

Through the use of multiple order forms the librarian had already devised a system whereby any newly-ordered book awaiting processing could be located on a moment's notice and its processing rushed if a faculty member requested this service. But processing space was in short supply, and the backlog of uncataloged books was growing larger; and more book funds were being made available. The librarian predicted that approximately thirty-five hundred volumes would stand in backlog by June 1962 . After several conferences the president suggested that perhaps summer catalogers might be of help in clearing the back$\log$. He authorized the librarian to try to locate several librarians with cataloging experience who might be free for the summer.

The librarian began to organize a plan of action. An advertisement asking for summer catalogers was placed in two professional journals. It was decided that since the Library of Congress cards (which had been ordered at the same time as the books) for nearly all new books were on hand, the aim of the project would be to catalog and classify the books and to get them shelved ready for use. Through multiple forms all processes could be readily controlled and the typing and filing of the cards could be done later.

The green slip of the multiple forms, in the book since its arrival, would become the temporary record for the public 
catalog as usual. The yellow slip would become the temporary record in the shelf list as usual. The pink slip, instead of being used as a faculty notice, would remain with the set of cards and, as usual, bear information for the typist to complete the set. Because the pink slip would be tied up for some weeks, faculty would be notified via the buff card from the onorder drawer as soon as the list of books added to the library was typed.

Much in the way of preparation for the project had to be very carefully planned. Problem spots in recataloging were cleared up as much as possible. Since these problems had been worked on over the past two years, quite a number were already under control. Subject headings were brought up to date through the basic list and supplements; the "flow of books through cataloging" routine was reviewed; decisions written on slips of paper were coordinated, reviewed and typed in readable form on sheets; sample book cards, pockets, and sets of catalog cards were assembled. A copy of this material was made for each summer cataloger. Every effort was made to have as many things as possible written down to guide the catalogers.

The pink slips from the multiple forms were arranged according to the suggested Dewey classification number found on the Library of Congress card. This would allow the catalogers to work on the new books by subject blocks.

Meanwhile, replies to the advertisements (largely from school librarians free for the summer) were collected and answered by the librarian. References of the applicants were checked. Salaries were based on weekly portions of beginning annual salaries. The final selection of candidates was set at three because of limited finances and work space. Dates for working and accommodations for living were arranged according to individual preferences, and the appointments were confirmed by the president of the college.
In due time the day arrived when the visiting catalogers appeared and sat down with the prepared detail sheets and the sample sets of cards. Blocks of books were pulled from the processing shelves according to the classified groups of pink slips, matched to their Library of Congress cards, and the catalogers began to catalog and classify the books and to send them on to the marking room. The annotated Dewey schedule was carefully consulted for deviations in this particular library, and the subject-heading book was in constant use.

The book cards and pockets were typed while the books were being marked. When these were pasted in and the marking revised, the books were spraylacquered and sent on for shelving. Meanwhile, the pink slip with the cataloger's corrections and directions for the typist was banded to the set of cards and filed alphabetically to await typing. The yellow slip was filed in the shelf-list and the green slip sent to the public catalog.

It was as simple as that. Of course, problem books (for example, books without Library of Congress cards, and books requiring special handling because of a conflict in the shelf-list) were shunted off to the regular cataloger who stood by to answer questions and generally supervise the work of the visiting catalogers. If she could solve the problem quickly, which happened in many cases, the book was processed then, but if the matter was a knotty problem the book was reshelved to await her attention later. Surprisingly, only a hundred or so volumes were put back for later consideration.

The project operated for an over-all period of ten weeks with one cataloger staying six weeks, another eight, and the third nine.

What were the results of the project? Perhaps the most important outcome was that the library had 3243 new books on the shelves ready for circulation; the processing room was empty and waiting for new purchases. The three catalogers 
each indicated valuable experiences. In fact, everyone connected with the project felt a sense of accomplishment.

One of the catalogers was from a college library in eastern Maryland. The venture had provided an opportunity for her to see another college library in operation and to carry back new ideas to her campus, where she was entering her second year as cataloger. Besides, she had enjoyed six delightful summer weeks in the mountains.

The second cataloger had worked for a number of years in an exclusive, highly academic, secondary-school library in an urban area of Michigan. He wanted to gain cataloging experience iñ an effort to advance himself professionally, and welcomed the sharing and learning processes of the project. He, too, enjoyed the mountain summer, making new friends, and living in a small community.

The third was from a New England junior high school library and felt he wanted to have some experience in a higher level library. He picked up the routines very quickly, and with his unusual bilingual ability in French and English (he was also a Spanish major) he found himself quite at home with the French and Spanish acquisitions awaiting processing. He brought back into play his knowledge of the authors and literary periods he had studied in college days and proved a very valuable asset to the team. He gained experience, as did also the others, of working with tools not available to him in his regular library.

The student assistant who marked the books and the library assistants who helped with technical details saw at first hand an alive project and enjoyed the company of these professional people. The regular cataloger was professionally stimulated by the contact with these alert visitors as they questioned and discussed the pros and cons of debatable issues. Some new policies were established for this particular library, and some old ones were defended.

Over-all, the librarian coordinated all of the processes, shaping this area or that area into line as the program moved forward. Summer school ran along simultaneously, and the assistant librarians in reference and circulation carried this detail.

There were some disadvantages in the project. First of all, despite the fact that the group assembled was fortunately most congenial and no pressure was applied to produce a specific amount of work, one of the catalogers felt fairly worn out after six weeks. Another experienced some boring subject blocks of books which ran along with no variety, even in adapting the Library of Congress cards. The marker, and with reason, began to tire towards the end of the ten weeks. The regular cataloger felt the strain of the constant decisions. There were no complaints or irritated nerves, and often the clock was ignored to complete a particular item; but several suggestions were made that perhaps the basic time of the project should be shortened. However, it was agreed that with the routine now checked out, another such project should run more smoothly.

A major drawback of the project was the lack of planning for extra help in typing, to move the sets of cards and to get them filed into the catalogs. At the end of the ten weeks this still had to be done. It would have been possible to provide typists and still to keep within a reasonable figure financially.

The success of the undertaking appeared to be so great that the president of the college suggested to the librarian that it might be well to plan for another project should the need for it appear again. With the extensive expansion program of Frostburg State Teachers College and the need to strengthen the library holdings over a short period of time, the repetition of such a program might be an answer to the scarcity of catalogers at this particular college. It might, in fact, be a partial solution to the shortage of cataloging staff in other college libraries. 